\title{
Distinct Murine Macrophage Receptor Pathway for Human Triglyceride-rich Lipoproteins
}

Sandra H. Gianturco, * Alice H.-Y. Lin, Shiah-Lian C. Hwang, Jill Young, Spencer A. Brown, David P. Via, and William A. Bradley The Department of Medicine, Baylor College of Medicine, and The Methodist Hospital, Houston, Texas 77030

\begin{abstract}
Murine P388D $_{1}$ macrophages have a receptor pathway that binds human hypertriglyceridemic very low density lipoproteins (HTG-VLDL) that is fundamentally distinct from the LDL receptor pathway. Trypsin-treated HTG-VLDL (trypVLDL), devoid of apolipoprotein (apo)-E, fail to bind to the LDL receptor, yet tryp-VLDL and HTG-VLDL cross-compete for binding to $\mathbf{P 3 8 8}_{1}$ macrophage receptors, indicating that these lipoproteins bind to the same sites. The specific, high affinity binding of tryp-VLDL and HTG-VLDL to macrophages at $4^{\circ} \mathrm{C}$ is equivalent and at $37^{\circ} \mathrm{C}$ both produce rapid, massive, curvilinear (receptor-mediated) triglyceride accumulation in macrophages.

Ligand blots show that P388D $_{1}$ macrophages express a membrane protein of $\sim 190 \mathrm{kD}$ (MBP190) that binds both tryp-VLDL and HTG-VLDL; this binding is competed by HTG-VLDL, trypsinized HTG-VLDL, and trypsinized normal VLDL but not by normal VLDL or LDL. The macrophage LDL receptor $(\sim 130 \mathrm{kD})$ and cellular uptake of $\beta$-VLDL, but not MBP 190 nor uptake of tryp-VLDL, are induced when cells are exposed to lipoprotein-deficient medium and decreased when cells are cholesterol loaded. Unlike the macrophage LDL receptor, MBP 190 partitions into the aqueous phase after phase separation of Triton X-114 extracts. An anti-LDL receptor polyclonal antibody blocks binding of HTG-VLDL to the LDL receptor and blocks receptor-mediated uptake of $\beta$-VLDL by P388D $_{1}$ cells but fails to inhibit specific cellular uptake of tryp-VLDL or to block binding of tryp-VLDL to MBP 190. Human monocytes, but not human fibroblasts, also express a binding protein for HTG-VLDL and tryp-VLDL similar to MBP 190 . We conclude that macrophages possess receptors for abnormal human triglyceride-rich lipoproteins that are distinct from LDL receptors in ligand specificity, regulation, immunological characteristics, and cellular distribution. MBP 190 shares these properties and is a likely receptor candidate for the high affinity uptake of TGrich lipoproteins by macrophages.
\end{abstract}

\section{Introduction}

VLDL from hypertriglyceridemic (HTG)' ${ }^{1}$ subjects and chylomicrons are the only native human plasma lipoproteins reported to cause rapid, massive, receptor-mediated lipid accu-

Address reprint requests to Dr. Gianturco and Dr. Bradley at the University of Alabama at Birmingham, Department of Medicine, University Station, Birmingham, AL 35294.

Received for publication 23 March 1987 and in revised form 27 June 1988.

Portions of this manuscript have appeared in abstract form (1986. Circulation. 74(II):785); and (1987. Circulation. 76(IV):422).

J. Clin. Invest.

(C) The American Society for Clinical Investigation, Inc.

$0021-9738 / 88 / 11 / 1633 / 11 \$ 2.00$

Volume 82, November 1988, 1633-1643 mulation in macrophages in vitro (1-3). The macrophage receptor responsible for uptake of human chylomicrons and HTG-VLDL appeared to be distinct from the LDL receptor both functionally (1-3) and genetically (4). Uptake of these human triglyceride-rich lipoproteins was originally ascribed to the " $\beta$-VLDL receptor" (1-5). The $\beta$-VLDL receptor was thought to be distinct from the LDL receptor because original studies demonstrated that receptors of macrophages preincubated in the presence of serum (conditions that downregulate LDL receptor activity in fibroblasts) efficiently mediated uptake of canine $\beta$-VLDL but not LDL (6).

Recent studies, however, indicate that the uptake of $\beta$ VLDL by murine macrophages is mediated primarily by the LDL receptor $(7,8)$. Macrophages cultured under conditions that maximize LDL receptor activity (cells preincubated in lipoprotein-deficient serum) bound canine $\beta$-VLDL with high affinity, via apoE, whereas both human and murine LDL bound poorly, indicating the murine macrophage LDL receptor efficiently binds lipoproteins through apoE but not apoB (7). Likewise, uptake of rat $\beta$-VLDL and chylomicron remnants by murine peritoneal, $\mathrm{P} 388 \mathrm{D}_{1}$, and $\mathrm{J774}$ macrophages appeared to be mediated primarily by the LDL receptor since uptake was inhibited by anti-LDL receptor antibodies (8).

Other studies suggest, however, that there are additional receptors on macrophages distinct from the LDL receptor, both functionally and genetically (1-5), that bind certain human triglyceride-rich lipoproteins. Receptors present on macrophages with downregulated LDL receptor activity continue to bind human chylomicrons $(1-5,9)$, hypertriglyceridemic very low density lipoproteins $S_{\mathrm{f}} 100-400$ (HTG$\left.\operatorname{VLDL}_{1}\right)(1-3,5)$ and thrombin-treated HTG-VLDL $1(2,3)$ with high affinity. Although $\mathrm{HTG}_{\mathrm{VLDL}}$ also bind to LDL receptors with high affinity (10-13), neither chylomicrons (14) nor thrombin-treated HTG-VLDL 1 (10-13) bind to LDL receptors.

Fogelman, Edwards, and co-workers have reported that macrophages possess receptors for human chylomicrons and rabbit $\beta$-VLDL that are genetically as well as functionally distinct from the LDL receptor $(4,9,15)$. Monocyte-derived macrophages from a subject with homozygous familial hypercholesterolemia (FH) (4), as well as macrophages (9) and endothelial cells (15) isolated from the homozygous WHHL rabbit bound human lymph and plasma chylomicrons. Such studies indicate that a macrophage/endothelial cell receptor that binds human chylomicrons is genetically distinct from the LDL receptor $(4,9,15)$.

1. Abbreviations used in this paper: HTG-VLDL $\mathrm{L}_{1}$, hypertriglyceridemic very low density lipoproteins; LPDS, lipoprotein-deficient serum; MBP 190, macrophage binding protein of $\sim 190 \mathrm{kD}$; PPACK, D-phenylalanyl-L-prolyl-L-arginine chloromethyl ketone; TG, triglyceride; $\mathrm{VLDL}_{1}, S_{\mathrm{f}}$ 100-400; tryp-VLDL, trypsin-treated and repurified VLDL; $\beta$-VLDL ${ }_{1}$, VLDL from cholesterol-fed rabbits with $\beta$-electrophoretic mobility; WHHL, Watanabe heritable hyperlipidemia. 
To facilitate studies of the macrophage receptor for uptake of human plasma chylomicrons and HTG-VLDL, we developed conditions that maximized the expression of this pathway and minimized expression of the LDL receptor pathway in the long-term murine macrophage line $P_{388 D_{1}}(2)$. When grown on complete serum, $\mathrm{P} 388 \mathrm{D}_{1}$ macrophages express very iow levels of the $\operatorname{LDL}$ receptor $(2,16)$ and do not secrete apoE (2). Secretion of apoE and/or expression of the LDL receptor would introduce ambiguity into the interpretation of the cell studies described in this report, since apoE mediates binding of VLDL $S_{\mathrm{f}} 60-400$ to the LDL receptor $(10-13,17)$. The characteristics of the pathway for HTG-VLDL uptake by P388D $_{1}$ cells are like those previously described in freshly isolated, unstimulated murine peritoneal macrophages $(1,2)$. Competition studies indicated that the macrophage receptor that binds iodinated HTG-VLDL 1 also binds chylomicrons, HTGVLDL, and $\beta$-VLDL from cholesterol-fed rabbits, but not LDL or acetyl LDL $(2,3)$. Moreover, thrombin-treated HTGVLDL, which do not bind to LDL receptors in cultured human fibroblasts $(10-12)$ or ligand blot partially purified bovine LDL receptors (13), nevertheless compete as well as or better than native HTG-VLDL for the uptake and degradation of iodinated HTG-VLDL $L_{1}$ by murine $\mathrm{P} 388 \mathrm{D}_{1}$ macrophages (2) or peritoneal macrophages (3), suggesting the uptake was not via the LDL receptor.

The studies we now report indicate that macrophages possess receptors for abnormal human triglyceride-rich lipoproteins that are distinct from LDL receptors in ligand specificity, regulation, immunological characteristics, and cellular distribution. A specific macrophage membrane binding protein distinct from the LDL receptor shares these properties and is a candidate for this alternate receptor.

\section{Methods}

Cells and cell culture. The murine macrophage cell line P388D (Salk $_{1}$ Institute Cell Repository, La Jolla, CA) was cultured in RPMI 1640 (high glucose) supplemented with $1 \%$ glutamine, 10\% fetal bovine serum (Gibco Laboratories, Grand Island, NY), $100 \mu \mathrm{g} / \mathrm{ml}$ penicillin, and $100 \mathrm{U} / \mathrm{ml}$ streptomycin $(2,18)$. Cells were maintained in $100-\mathrm{mm}$ dishes in a humidified incubator $\left(5 \% \mathrm{CO}_{2}\right)$ at $37^{\circ} \mathrm{C}$. Human mononuclear cells were isolated from whole blood of a healthy, normal subject by the method of Böyum (19) and placed in tissue culture dishes for $2 \mathrm{~h}$ in RPMI 1640 medium containing 20\% autologous serum to allow monocytes to adhere (20). After nonadherent cells were removed, the monocytes were incubated in complete medium for $3 \mathrm{~d}$ in a $\mathrm{CO}_{2}$ incubator before study.

For binding and triglyceride accumulation studies, $\sim 2 \times 10^{5}$ $\mathrm{P}_{388 \mathrm{D}_{1}}$ cells were seeded in $2 \mathrm{ml}$ of complete medium into $60 \times 15$ $\mathrm{mm}$ dishes. Cultures were refed $24 \mathrm{~h}$ later with complete medium, and on the second day the medium was removed. After washing twice with saline, the cells were incubated in $2 \mathrm{ml}$ of serum-free RPMI 1640 containing the desired concentration of lipoprotein, as indicated in the figures. For ligand blotting studies, $\sim 5 \times 10^{5}$ cells were seeded in 10 $\mathrm{ml}$ of complete medium in $100 \times 15 \mathrm{~mm}$ dishes and harvested $24 \mathrm{~h}$ later.

For binding, uptake, and degradation studies, duplicate dishes of cells and empty dishes were incubated with labeled lipoproteins alone and in the presence of indicated quantities of unlabeled lipoprotein at $4^{\circ}$ or $37^{\circ} \mathrm{C}$ for up to $4 \mathrm{~h}$ as indicated in the figure legends. All experiments are conducted at 2-4 h of incubation in the absence of serum components other than lipoproteins. Total cell-associated radioactivity (representing both surface-bound and internalized) was determined after the cells were washed three times with chilled buffer containing 2 $\mathrm{mg}$ albumin/ml and twice with albumin-free buffer (18). The amount of noniodide, nonlipid, TCA-soluble radioactivity in the medium was used as a measure of iodinated lipoprotein degradation (18). There was no evidence of deiodination of ${ }^{125} \mathrm{I}$-monotyrosine after the cellular degradation of radiolabeled apoproteins (2). Each value was corrected by subtracting the amount "bound" or degraded in control dishes that contained no cells. Specific binding, uptake, and degradation curves were calculated by subtracting the curve generated by plotting the amount of ${ }^{125}$ I-labeled lipoprotein processed by cells in the presence of excess unlabeled homologous lipoprotein (these plots were linear) from the curve representing the amount bound in the absence of unlabeled lipoproteins (curvilinear).

Triglyceride mass was determined using an enzymatic kit (catalogue No. 701912; Boehringer Mannheim, Indianapolis, IN) as described previously (2).

Lipoproteins. Plasma was obtained either from fasting subjects with normal lipid values for isolation of normal VLDL, LDL, and lipoprotein-deficient serum (LPDS) or from fasting patients with types 4 and 5 lipoprotein profiles for HTG-VLDL and chylomicrons. Subjects were fasted for $14 \mathrm{~h}$ before blood donation. The diagnoses were based on commonly used criteria (21). Lipoproteins for cell studies were isolated (22) from fresh plasma containing $1 \mathrm{mM}$ EDTA, $1 \mathrm{mM} \mathrm{NaN}_{3}, 10 \mu \mathrm{M}$ PMSF (Sigma Chemical Co., St. Louis, MO), $10 \mu \mathrm{M}$ PPACK (Calbiochem-Behring Corp., La Jolla, CA), and $50 \mathrm{U}$ Trasylol/ml. VLDL were subfractionated through a discontinuous $\mathrm{NaCl}$ gradient from $d 1.063$ to 1.006 by Lindgren's cumulative flotation method (23), as previously detailed (12); only the largest subfraction, VLDL of $S_{\mathrm{f}} 100-400$ $\left(\mathrm{VLDL}_{1}\right)$, was used throughout this study. Chylomicrons were isolated by a 20 -min centrifugation in a SW 41 rotor at $12,000 \mathrm{rpm}$ and $23^{\circ} \mathrm{C}$ and washed three times through saline containing $1 \mathrm{mM}$ EDTA, $\mathrm{pH}$ 7.4. LDL were isolated at $d 1.03-1.05 \mathrm{~g} / \mathrm{ml}$ and washed at each density. $\beta$-VLDL were isolated from cholesterol-fed rabbits as previously described $(1,2)$. Total protein contents of the lipoproteins were obtained either by a modified Lowry $(24,25)$ or by amino acid analysis. Characteristics of VLDL subclasses so isolated are detailed elsewhere $(1,12)$.

HTG-VLDL were incubated with $200 \mathrm{U}$ of purified human $\alpha$ thrombin/mg of apoprotein, thrombin inactivated with hirudin (1 $\mathrm{nM}$ ), or with trypsin (1:100, wt/wt) for $2 \mathrm{~h}$ at $37^{\circ} \mathrm{C}$ in $0.15 \mathrm{M} \mathrm{NaCl}, 20$ $\mathrm{mM}$ Tris, $\mathrm{pH} 7.4$, (buffer), or with buffer alone (control) as described previously $(10-13,26) ; 10 \mathrm{mM} \mathrm{CaCl} 2$ was included in the thrombin incubations. Aliquots of the thrombin-treated and control lipoproteins were then recentrifuged through a discontinuous salt gradient $(d$ $1.05-1.006 \mathrm{~g} / \mathrm{ml}$ ) to reisolate the HTG-VLDL $L_{1}$. Trypsin-treated VLDL were chromatographed on immobilized $\rho$-aminobenzamidine linked to Sepharose to remove active trypsin (27) before reisolation by gradient flotation as described above. Each preparation of native HTG-VLDL or of protease-modified HTG-VLDL used in the macrophage studies was also tested for its ability to cause LDL receptor-mediated HMG-CoA reductase suppression in cultured normal human skin fibroblasts, a sensitive measure of LDL receptor determinants present on the lipoprotein (10-12), and/or for its ability to ligand blot partially purified bovine LDL receptors after electrophoresis and transfer to nitrocellulose paper (13). ApoE and its fragments were detected immunochemically after electrophoretic transfer (Western blotting) $(10,12)$. In contrast to $\mathrm{HTG}_{\mathrm{VLDL}}$, thrombin-treated and trypsin-treated HTG-VLDL ${ }_{1}$ used in these studies no longer suppressed 3-hydroxy-3-methyl-glutaryl-CoA (HMG)-CoA reductase activity in normal human fibroblasts $(10,11)$ nor were they capable of ligand blotting electrophoretically isolated bovine adrenal LDL receptors (13) due to cleavage of the thrombin-accessible apoE by thrombin or total removal of apoE by trypsin, as determined by immunochemical blotting and RIA $(10-12,26)$.

For binding and ligand blotting studies, lipoproteins were iodinated by a modification of the iodine monochloride method of McFarland (28). Free iodine was removed by gel filtration and extensive dialysis. Samples were filtered (0.45 $\mu \mathrm{m}$ Millex; Millipore Corp., Bedford, MA) immediately before use; specific activities ranged from 100 to 200 
$\mathrm{cpm} / \mathrm{ng}$ protein. Less than $10 \%$ of the label was extractable into organic solvent.

Bovine $L D L$ receptor preparation. The LDL receptor was partially purified from bovine adrenal cortical membranes solubilized in Triton $\mathrm{X}-100$ and chromatographed on DEAE-cellulose, for use in ligand blots and further purified by affinity chromatography on LDL-Sepharose for the production of anti-LDL receptor antibodies as described by Schneider (29).

Antibody production. $100 \mu \mathrm{g}$ of affinity-purified LDL receptor, one major band on 6\% SDS PAGE, in Freund's complete adjuvant were injected subcutaneously into multiple sites on the backs of New Zealand white rabbits. After 4 wk a second injection of $50 \mu \mathrm{g}$ i.m. was given. The rabbits were bled 2 wk later. The IgG fraction of preimmune serum and immune serum were purified by precipitation of IgGs from serum with $50 \%$ saturated ammonium sulfate. After dialysis against $0.025 \mathrm{M}$ Tris- $\mathrm{HCl}, 0.035 \mathrm{M} \mathrm{NaCl}, \mathrm{pH} 8.8$, the protein mixture was applied to a DEAE-Trisacryl $M$ column and the IgGs eluted with the same buffer (30). IgG purity was assessed by SDS-PAGE under reducing and nonreducing conditions; gels were stained with Coomassie Blue.

Detergent solubilization of macrophages for ligand blotting.

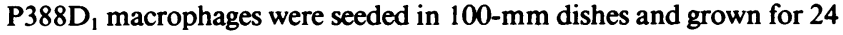
$h$ in complete medium. The cells from 10 dishes $(100 \times 15 \mathrm{~mm})$ were placed on ice and scraped with a rubber policeman into $3 \mathrm{ml}$ of chilled buffer I per dish $(0.15 \mathrm{mM} \mathrm{NaCl}, 50 \mathrm{mM}$ Tris- $\mathrm{HCl}, \mathrm{pH} 8.0,50 \mathrm{U}$ Aprotinin/ml, $10 \mathrm{mM}$ leupeptin, and $10 \mu \mathrm{M}$ PMSF). PMSF in dioxane was added to buffer I immediately before the cells were harvested. The cells were pelleted $\left(1,000 \mathrm{rpm}, 4^{\circ} \mathrm{C}, 5 \mathrm{~min}\right)$ and resuspended in buffer I. Plasma membranes were prepared by homogenizing cells ( 10 strokes by hand), removing all debris (spin for $10 \mathrm{~min}$ at $4^{\circ} \mathrm{C}$ and $800 \mathrm{rpm}$ ), and precipitating plasma membranes by spinning at $100,000 \mathrm{~g}$ for $1 \mathrm{~h}$ at $4^{\circ} \mathrm{C}$. Whole cell pellets or plasma membranes were solubilized as follows $(31,32)$ : Triton $\mathrm{X}-114$, which forms two phases above $25^{\circ} \mathrm{C}$ (31), was added to a final concentration of $1 \%$ (vol/vol); the preparation was then vortexed and placed on ice for $15 \mathrm{~min}$. The suspension was centrifuged in thick walled tubes for $60 \mathrm{~min}$ at $35,000 \mathrm{rpm}$ in a 50.3 rotor at $4^{\circ} \mathrm{C}$. The supernatant was incubated at $37^{\circ} \mathrm{C}$ for $15 \mathrm{~min}$ and the cloudy suspension was overlayed on a cushion composed of $6 \%$ sucrose, $50 \mathrm{mM}$ Tris $\mathrm{pH} 8.0,0.6 \%$ Triton $\mathrm{X}-114$ at $37^{\circ} \mathrm{C}(1 \mathrm{ml}$ cushion $/ 3 \mathrm{ml}$ suspension). Centrifugation for $5 \mathrm{~min}$ at $1,000 \mathrm{rpm}$ achieved phase separation: the detergent phase was at the bottom of the tube as an oily drop and contained the LDL receptor, when present (32); the upper phase (the aqueous phase) contained membrane proteins that bound HTG-VLDL and trypsinized HTG-VLDL, as determined by ligand blotting.

Ligand blotting. One dimensional electrophoresis was performed on $6 \%$ polyacrylamide slab gels containing $0.1 \%$ SDS using the buffer system of Laemmli (33). $40 \mu$ l sample was applied per well, containing 40-80 $\mu \mathrm{g}$ of protein, and electrophoresed in a Minigel apparatus (BioRad Laboratories, Richmond, CA) at room temperature for $45 \mathrm{~min}$ at $200 \mathrm{~V}$, except for the blots shown in Figs. 5 and 12, which were obtained after electrophoresis on $14 \times 8.5 \times 0.15 \mathrm{~cm}$ slab gels followed by a 16-h electrotransfer (13). Minigels were electrotransferred to nitrocellulose for $3 \mathrm{~h}$ at $100 \mathrm{~V}$ and $10^{\circ}$, conditions that permitted complete transfer of prestained standards and transferred cellular proteins, as determined by Coomassie Blue staining of the gel after transfer. For ligand blotting (34), the nitrocellulose strips were then incubated with blocking buffer ( $50 \mathrm{mM}$ Tris- $\mathrm{HCl}, 2 \mathrm{mM} \mathrm{CaCl} 2,5 \%$ Carnation nonfat dry milk (Carnation Co., Los Angeles, CA), and $90 \mathrm{mM} \mathrm{NaCl}$ at pH 8.0) for $1 \mathrm{~h}$ at room temperature on a shaker, then incubated in $0.5 \%$ casein-buffer containing the indicated amount of lipoproteins for $3 \mathrm{~h}$ at room temperature on a shaker, then washed with buffer without casein (three times, 5 min each), dried, and visualized by autoradiography. For calculation of lipoprotein particle concentrations, the following molecular weights and percentages of protein were used: HTG$\mathrm{VLDL}_{1}, 30 \times 10^{6} \mathrm{kD}, 6.0 \%$ protein; tryp-VLDL, $30 \times 10^{6} \mathrm{kD}, 4.15 \%$ protein; LDL, $2.2 \times 10^{6}, 25 \%$ protein. For estimation of apparent molecular weights, the following prestained standards were electro- phoresed and transferred: myosin (200 kD), phosphorylase B (97.4 $\mathrm{kD})$, bovine serum albumin (68 kD), ovalbumin (43 kD), $\alpha$-chymotrypsinogen $(25.7 \mathrm{kD}), \beta$-lactoglobulin $(18.4 \mathrm{kD})$, and lysozyme $(14.3$ $\mathrm{kD})$. In this $6 \%$ gel system, the latter three proteins were not separated and ran as one band near the dye front.

\section{Results}

Competition studies indicate that trypsinized HTG-VLDL devoid of apoE and HTG-VLDL bind to the same sites on macrophages. Evidence that macrophages possess receptors distinct from the LDL receptor in ligand specificity come from studies that show that apoE is not required for the specific, receptormediated uptake of HTG-VLDL. By contrast, the LDL receptor of cultured human fibroblasts $(10-12,26)$, of murine macrophages (7), or the partially purified receptor from bovine adrenals (13) absolutely requires apoE of an appropriate conformation for binding of large VLDL.

One criterion used as evidence that different particles bind to the same receptor is cross-competition in competitive binding studies. Thus, to determine if apoE was required for the binding of large triglyceride-rich particles to the macrophage receptor, we hydrolyzed $\mathrm{HTG}_{\mathrm{VLDL}}$ with trypsin, to remove all immunochemically detectable apoE and abolish binding to the LDL receptor, for use in competitive binding studies $(10-13,26)$. The removal of apoE of HTG-VLDL by trypsinization was monitored by immunochemical electrophoretic (Western) blotting. No apoE fragments were detected in these experiments (data not shown), as was previously observed (10-13). These same trypsin-treated HTG-VLDL ${ }_{1}$ were tested in two additional ways as controls to show that the LDL receptor binding determinants were indeed lost upon trypsinization. First, as previously established (10-12, 26), trypsinization abolished the ability of these HTG-VLDL to suppress HMGCoA reductase activity in cultured human fibroblasts (reductase suppression being a sensitive indicator of receptor-mediated uptake of the lipoprotein). Second, these trypsinized HTG-VLDL ${ }_{1}$ failed to bind directly to DEAE cellulose-purified bovine LDL receptors as determined by ligand blotting, as previously reported (13).

As seen in Fig. 1, trypsin-treated HTG-VLDL ${ }_{1}$, devoid of apoE, compete as well as native HTG-VLDL for the binding of ${ }^{125} \mathrm{I}-\mathrm{HTG}-\mathrm{VLDL}$ to $\mathrm{P} 388 \mathrm{D}_{1}$ macrophages. Furthermore, reverse competition experiments indicate that native HTG$\mathrm{VLDL}_{1}$ compete equally and effectively for binding of ${ }^{125} \mathrm{I}$ HTG-VLDL ${ }_{1}$, of ${ }^{125}$ I-trypsinized-HTG-VLDL ${ }_{1}$, and of control (buffer incubated) ${ }^{125} \mathrm{I}_{-H T G-V L D L}$ (Fig. 2). Six separate competition studies with $\mathrm{HTG}_{\mathrm{VLDL}}$ from four different hypertriglyceridemic subjects demonstrated that trypsinized HTG-VLDL $L_{1}$ and native HTG-VLDL ${ }_{1}$ competed for the same binding sites on $\mathrm{P} 388 \mathrm{D}_{1}$ macrophages.

The similar cross-competitiveness of HTG-VLDL 1 and trypsinized HTG-VLDL $L_{1}$ for binding to macrophages suggests that these lipoproteins bind to equivalent sites. The demonstration that HTG-VLDL compete as efficiently after removing some apoE in thrombin-treated HTG-VLDL (2) or all apoE (trypsin-treated HTG-VLDL, Figs. 1 and 2) for binding to macrophages with downregulated LDL receptors indicates that these large triglyceride-rich lipoproteins bind primarily to sites with ligand requirements distinct from those of the LDL receptor.

Trypsin-treated $H T G-V L D L_{1}$ devoid of apoE, like HTG$V L D L$, bind with high affinity to macrophages. A second crite- 


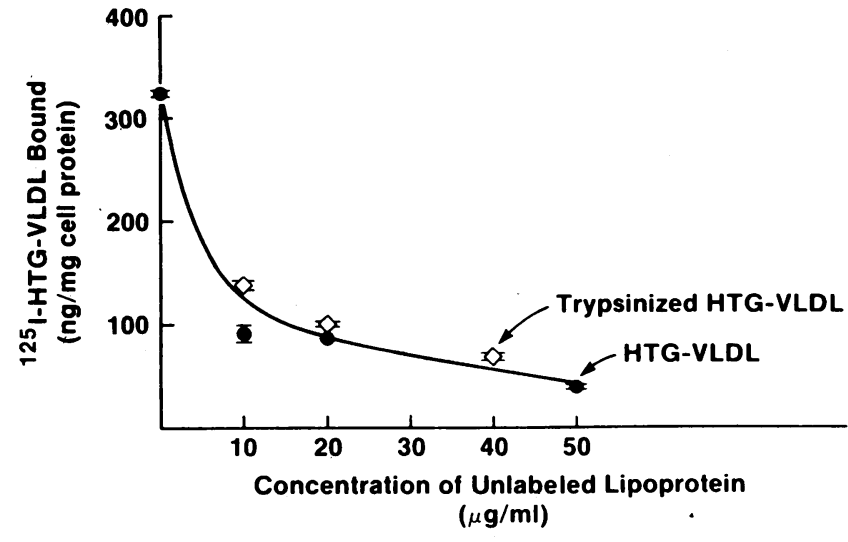

Figure 1. Trypsinized HTG-VLDL devoid of apoE effectively compete with the binding of ${ }^{125}$ I-HTG-VLDL. Cells were grown to $\sim 60 \%$ confluency in $60-\mathrm{mm}$ dishes in complete medium for $2 \mathrm{~d}$ and washed. Medium containing ${ }^{125}$ I-HTG-VLDL $S_{\mathrm{f}} 60-400$ (5 $\mu \mathrm{g}$ protein $/ \mathrm{ml}$ ), in the absence or in the presence of indicated levels of unlabeled homologous HTG-VLDL (•) or trypsinized homologous HTG-VLDL (prepared as described in Methods), $(\diamond)$, were added to duplicate dishes and incubated in a humidified $\mathrm{CO}_{2}$ incubator for 2 $\mathrm{h}$ at $37^{\circ} \mathrm{C}$. Cells were washed extensively with albumin-containing buffer and dissolved in $2.0 \mathrm{ml}$ of $0.1 \mathrm{~N} \mathrm{NaOH}$. Radioactivity associated with the cell lysate represents ${ }^{125} \mathrm{I}-\mathrm{HTG}-\mathrm{VLDL}_{1}$ binding. The VLDL were obtained from a subject with type 4 hypertriglyceridemia. Each data point represents the average of values from two dishes, expressed as nanograms of ${ }^{125} \mathrm{I}-\mathrm{HTG}$-VLDL per milligram cell protein, with ranges indicated by error bars.

rion for receptor binding is that the binding curves exhibit a high affinity component (curvilinearity) as opposed to low affinity binding only (linearity). Direct binding studies were undertaken to exclude the possibility that the competition observed in Fig. 1 by trypsinized VLDL was nonspecific and due to a marked increase in nonspecific adsorption to cells after trypsinization. Direct binding studies at $4^{\circ} \mathrm{C}$ of iodinated lipoproteins demonstrate that both trypsinized HTG-VLDL ${ }_{1}$ and HTG-VLDL 1 bind to macrophages in a high affinity, curvilinear manner, indicative of receptor binding (Fig. 3).

The binding of iodinated trypsinized HTG-VLDL in the absence of unlabeled VLDL (total binding) to macrophages was similar to that of native ${ }^{125} \mathrm{I}_{-H T G} \mathrm{VLDL}_{1}$ (Fig. 3, upper

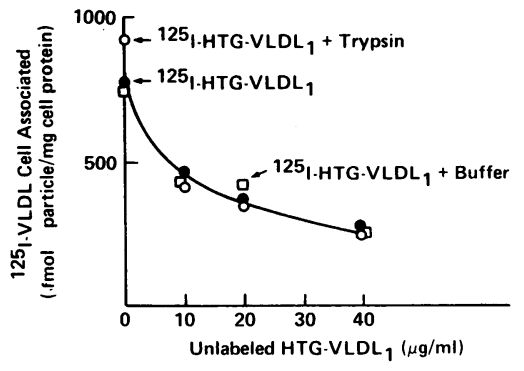

Figure 2. Binding of ${ }^{125}$ I-HTG-VLDL $_{1}$ and trypsinized ${ }^{125}$ I-HTG$\mathrm{VLDL}_{1}$ is equally competed by native HTGVLDL. Cells were grown in complete medium for $2 \mathrm{~d}$ and washed as described in the legend to Fig. 1 and Methods. Duplicate dishes of the cells were incubated with medium containing $5 \mu \mathrm{g} / \mathrm{ml}$ of native ${ }^{125} \mathrm{I}_{-} \mathrm{HTG}-\mathrm{VLDL}_{1}(\bullet),{ }^{125} \mathrm{I}_{-} \mathrm{HTG}-\mathrm{VLDL}_{1}$ incubated with trypsin and reisolated (O), or ${ }^{125}$ I-HTG-VLDL incubated with buffer and reisolated $(\square)$ in the absence or presence of indicated concentrations of unlabeled native $\mathrm{HTG} \mathrm{VLDL}_{1}$ for $2 \mathrm{~h}$ at $37^{\circ} \mathrm{C}$. The cells were washed and cell associated radioactivity was then determined as described in Methods. Each data point represents the average of values from duplicate dishes, which varied by $<5 \%$.

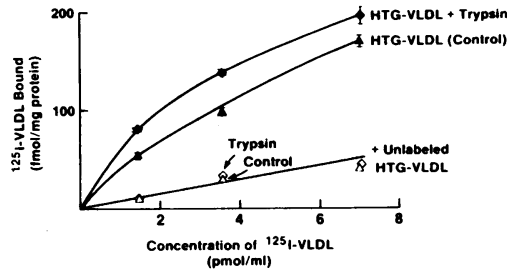

Figure 3. Direct binding study of ${ }^{125}$ I-HTGVLDL and ${ }^{125}$ I-trypsinized-HTG-VLDL devoid of apoE to $\mathrm{P}_{388 \mathrm{D}_{1}}$ macrophages. Cells were grown as described in the legend of Fig. 1. Duplicate dishes of cells were incubated with medium containing indicated quantities of ${ }^{125} \mathrm{I}$ HTG-VLDL ${ }_{1},(\Delta, \Delta)$ or ${ }^{125}$ I-trypsinized-HTG-VLDL, $(\diamond, \diamond)$ alone (closed symbols) and with excess unlabeled HTG-VLDL (100 $\mu \mathrm{g}$ protein $/ \mathrm{ml}$ ), (open symbols) for $2 \mathrm{~h}$ at $4^{\circ} \mathrm{C}$. The cells were washed extensively with albumin-containing buffer and dissolved in $0.1 \mathrm{~N} \mathrm{NaOH}$; radioactivity of the cell lysate represents binding of the iodinated lipoprotein and is plotted as a function of the amount of labeled lipoprotein present in the medium; concentrations are calculated on the basis of VLDL $S_{\mathrm{f}} 100-400$ molecular weight of $30 \times 10^{6}$ and $65 \%$ triglyceride (12) after determination of triglyceride mass. Each point represents the average of values from duplicate dishes; range is indicated by bars. The HTG-VLDL were obtained from a subject with type 4 hypertriglyceridemia. Trypsinized HTG-VLDL were prepared and reisolated after removal of trypsin as described in Methods.

curves). The total binding of both trypsinized HTG-VLDL 1 and native HTG-VLDL ${ }_{1}$ was effectively and equally competed by unlabeled $\mathrm{HTG}-\mathrm{VLDL}_{1}$, indicating that the nonspecific (not competable) binding of trypsinized HTG-VLDL 1 to macrophages was the same as that of control HTG-VLDL (Fig. 3, lower line). This experiment indicates there was no decrease in specific receptor binding of HTG-VLDL after removal of apoE by trypsinization.

Partial or total removal of apoE from $H T G-V L D L_{1}$ does not diminish the massive, rapid, saturable triglyceride accumulation induced by $H T G-V L D L_{1}$ in $P 388 D_{1}$ macrophages. A third criterion for receptor binding is that binding of the ligand to the receptor triggers a physiologic response in the cell. Receptor-mediated uptake of HTG-VLDL at physiological concentrations by macrophages leads to a massive, rapid, curvilinear accumulation of intracellular triglyceride after uptake, lysosomal hydrolysis, and reesterification in murine peritoneal (1) or P388D $\mathrm{D}_{1}$ macrophages (2). As shown in Fig. 4, trypsinized HTG-VLDL 1 devoid of apoE and native HTG-VLDL pro- $_{1}$ duce similar triglyceride accumulation. As is also shown, thrombin-treated HTG-VLDL were also as effective as native HTG-VLDL $L_{1}$ in stimulating rapid, saturable triglyceride engorgement. HTG-VLDL 1 treated with hirudin-inactivated thrombin indicates that thrombin, if present in the VLDL, had no effect on triglyceride accumulation.

The failure of thrombin- and trypsin-treatment to diminish the rapid, saturable triglyceride accumulation in macrophages induced by HTG-VLDL, while abolishing its interaction with LDL receptors, is highly reproducible. Triglyceride accumulation experiments with similar results have been performed seven times with five trypsinized HTG-VLDL 1 preparations from four hypertriglyceridemic subjects and with five preparations of thrombin-treated HTG-VLDL ${ }_{1}$ from four hypertriglyceridemic subjects. In no case was the protease-treated HTG-VLDL less effective than native HTG-VLDL in stimulating cellular triglyceride accumulation.

These studies demonstrate that the apoE required for binding of HTG-VLDL 1 to the LDL receptor, the thrombin-accessible apoE $(9-12,29)$, is not required for HTG-VLDL $\mathrm{L}_{1}$ to 


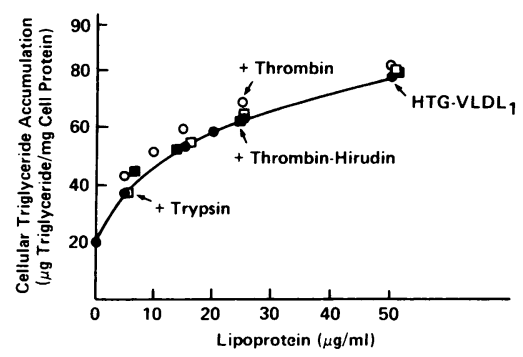

Figure 4. Effects of trypsin- and thrombintreatment of HTGVLDL on its ability to stimulate triglyceride accumulation in P388D 1 macrophages. Cells were grown as described in the legend to Fig. 1 and in Methods. Indicated amounts of lipoproteins were added to duplicate dishes and incubated for $4 \mathrm{~h}$ at $37^{\circ} \mathrm{C}$. The cells were washed extensively with albumin-containing buffer and the lipids were extracted in situ with hexane:isopropanol and the triglyceride mass measured enzymatically, as described in Methods. HTG-VLDL 1 was from a patient with type 4 hypertriglyceridemia. Each point represents the average from duplicate dishes. The triglyceride mass accumulated by the cells is plotted as a function of the amount of lipoprotein protein present in the medium. HTG-VLDL $1(\bullet)$; HTG-VLDL treated with trypsin (ם); HTG-VLDL treated with human $\alpha$ thrombin (o); and HTG-VLDL treated with hirudin-inactivated thrombin ( $₫$ ). Lipoproteins were prepared as described in Methods.

produce rapid, saturable receptor-mediated triglyceride accumulation in macrophages. Moreover, the failure of trypsin treatment to diminish the ability of HTG-VLDL 1 to induce saturable triglyceride accumulation while totally removing immunochemically detectable apoE indicates that apoE is not even necessary for this process. This suggests that macrophage uptake of triglyceride-rich lipoproteins can be mediated by an alternate receptor other than the LDL receptor.

Ligand blotting analysis identifies a $190 \mathrm{kD}$ macrophage protein (MBP 190) that binds trypsinized VLDL and HTG$V L D L$. Analogous to the approach used for the LDL receptor (34), we have used ligand blotting techniques to identify a macrophage membrane binding protein potentially involved in the alternate pathway for receptor-mediated uptake of triglyceride-rich lipoproteins. Ligand blots demonstrate that a protein from macrophage membranes or whole macrophages solubilized with Triton $\mathrm{X}-114$ and partitioned into the aqueous phase binds both HTG-VLDL and trypsinized HTGVLDL devoid of apoE. By contrast, the LDL receptor partially purified from the bovine adrenal cortex binds HTG-VLDL but not trypsinized VLDL. As seen on the left of Fig. 5, native ${ }^{125}$ I-HTG-VLDL bind to the bovine LDL receptor (lane 1 ) and to a higher molecular weight protein $\left(\sim 190 M_{\mathrm{r}}\right)$ solubilized from macrophages (lanes 2 and 3). No macrophage LDL receptor was visible in the aqueous phase (Fig. 5) or detergent phase (not shown) of extracts of cells grown under these conditions chosen to minimize macrophage LDL receptor expression (2). On the right side of Fig. 5, the nitrocellulose strips were incubated with iodinated trypsinized HTG-VLDL. Lane 4 , containing the partially purified LDL receptor, is blank, demonstrating that it does not bind trypsinized VLDL devoid of apoE. In contrast, in lanes 5 and 6 , this same trypsinized VLDL retained the ability to bind to the $190 \mathrm{kD}$ MBP 190 . Thus, these ligand blots are consistent with the cell studies and strongly suggest that there are specific macrophage binding proteins distinct from LDL receptors in ligand characteristics, in that apoE is not required, and in apparent molecular weight, as indicated by its different electrophoretic mobility.

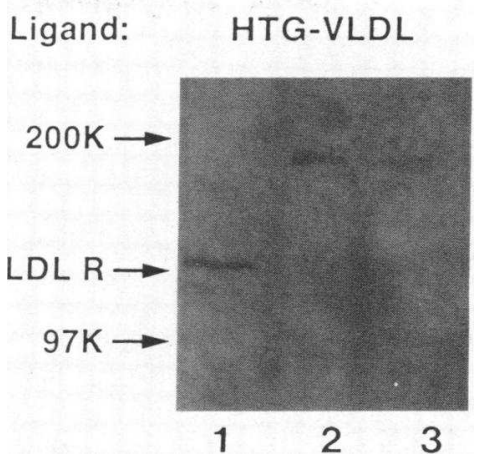

Tryp.-HTG-VLDL

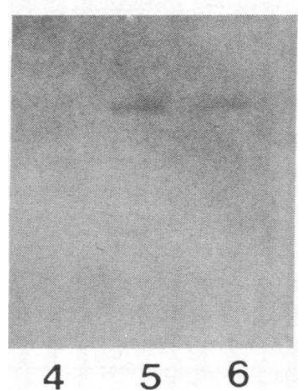

Figure 5. Ligand blotting of ${ }^{125} \mathrm{I}-\mathrm{HTG}-\mathrm{VLDL}$ and ${ }^{125} \mathrm{I}$-trypsinizedHTG-VLDL to partially purified bovine LDL receptors and $\mathrm{P}_{388 \mathrm{D}_{1}}$ macrophage proteins. $P 388 D_{1}$ cells were harvested after 24 h growth in complete medium. Partially purified bovine LDL receptors (lanes 1 and 4 ) and $\mathrm{P}_{388 \mathrm{D}_{1}}$ macrophage proteins extracted with Triton $\mathrm{X}-114$ and partitioned into the aqueous phase as described in Methods $(\sim 150 \mu \mathrm{g}$ protein, lanes 2 and $5 ; \sim 75 \mu \mathrm{g}$ protein, lanes 3 and 6 ) were electrophoresed on a $6 \%$ SDS polyacrylamide slab gel $(14 \times 8.5 \times 0.15 \mathrm{~cm})$ at $4^{\circ} \mathrm{C}$. After a 16 -h electrotransfer of the proteins to nitrocellulose, the nitrocellulose strips were incubated with ${ }^{125} \mathrm{I}-\mathrm{HTG}-\mathrm{VLDL}(10 \mu \mathrm{g} / \mathrm{ml}$, lanes $1-3)$ or ${ }^{125} \mathrm{I}$-trypsinized-HTGVLDL devoid of apoE ( $10 \mu \mathrm{g} / \mathrm{ml}$, lanes 4-6), washed, dried, and exposed to X-OMAT AR film for $16 \mathrm{~h}$. Arrows indicate the positions of the molecular weight $\left(M_{\mathrm{r}}\right)$ standards.

Competitive ligand blots indicate that MBP 190 is distinct from the LDL receptor. Aliquots of Triton X-114 aqueous

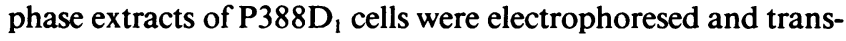
ferred to nitrocellulose strips for competitive binding studies to further characterize the ligand specificity of MBP 190 and to compare it with results from competitive binding studies in whole cells. The nitrocellulose strips were incubated with radioiodinated HTG-VLDL or trypsinized-HTG-VLDL in presence and absence of unlabeled competitors. As shown in Fig. $6,{ }^{125}$ I-tryp-HTG-VLDL is efficiently competed by unlabeled trypsinized HTG-VLDL (t-HTG-VLDL, lanes 2 and 3 ), trypsinized normal VLDL (t-Nor-VLDL, lanes 4 and 5), and native HTG-VLDL (lanes 8 and 9), but not by native normal VLDL (lanes 6 and 7) at 3- and 10-fold excess concentrations of unlabeled lipoprotein particles.

Conversely, labeled HTG-VLDL was effectively competed by itself (Fig. 7, lanes 2 and 3), by unlabeled trypsinized HTGVLDL (Fig. 7, lane 5), and by unlabeled trypsinized normal VLDL (Fig. 7, lane 6). By contrast, unlabeled LDL failed to compete with the binding of HTG-VLDL to MBP 190 even at a 20-fold excess particle concentration (Fig. 8, lanes 4 and 5), when only a 3- to 10-fold excess of trypsinized VLDL competed effectively (Fig. 8, lanes 2 and 3). This lack of effective competition by LDL for MBP 190 is consistent with the ineffective competition of LDL for the cellular uptake and degradation of HTG-VLDL by macrophages previously reported (1, 2). The binding of ${ }^{125} \mathrm{I}_{-} \mathrm{HTG}-\mathrm{VLDL}_{1}$ to MBP 190 was also competed by $\beta$-VLDL at a 10 -fold but not at a 3 -fold particle excess (data not shown), consistent with previous observations that $\beta$-VLDL competed for the uptake of HTG-VLDL by murine peritoneal (2) and $\mathrm{P} 388 \mathrm{D}_{1}$ macrophages (3). The affinity of $\beta$-VLDL for MBP 190 was less than that of HTG-VLDL or tryp-VLDL, as judged by visual inspection of direct as well as competitive ligand blots. 


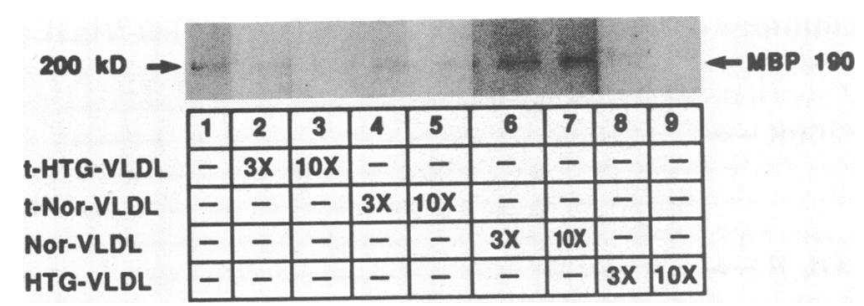

Figure 6. Binding of ${ }^{125} \mathrm{I}$-tryp-VLDL to MBP 190 is competed by tryp-HTG-VLDL, tryp-normal VLDL, and native HTG-VLDL, but not by native normal VLDL. P388D $\mathrm{D}_{1}$ macrophages were harvested after $24 \mathrm{~h}$ growth in complete medium and extracted with Triton $\mathrm{X}-114$; aliquots of aqueous phase extracts were electrophoresed in a Bio-Rad Minigel apparatus and electrotransferred as described in Methods. The blocked nitrocellulose strips were incubated with ${ }^{125} \mathrm{I}$ tryp-HTG-VLDL $L_{1}, 7 \mu$ g protein/ml, alone (lane 1) or with 3-fold and 10-fold excess levels of unlabeled trypsinized HTG-VLDL ( $t$-HTGVLDL, lanes 2 and 3), unlabeled trypsinized normal VLDL (lanes 4 and 5), unlabeled native normal $\mathrm{VLDL}_{1}$ (lanes 6 and 7), or unlabeled native HTG-VLDL (lanes 8 and 9), washed, dried, and exposed to film for $24 \mathrm{~h}$. Prestained molecular weight markers (Methods) were used to assign apparent molecular weights.

Cholesterol regulates the macrophage $L D L$ receptor and cellular uptake of $\beta-V L D L$ but not MBP 190 or cellular uptake of tryp-VLDL. Figs. 9-11 present evidence, first, from studies of whole cells, that macrophages have a receptor pathway for abnormal human triglyceride-rich lipoproteins different from the LDL receptor in terms of regulation and second, from ligand blots, that the 190-kD MBP and the macrophage LDL receptor share these regulatory differences.

For the experiment shown in Figs. 9-11, P388D 1 cells were divided into three groups. Each group was preincubated for 24 $\mathrm{h}$ in $(a)$ complete medium containing serum, $(b)$ in complete medium containing 25-hydroxycholesterol and cholesterol to downregulate the LDL receptor, or $(c)$ in medium containing LPDS to induce the LDL receptor. These preincubations had no significant effect on the uptake of ${ }^{125}$ I-trypsinized HTG-

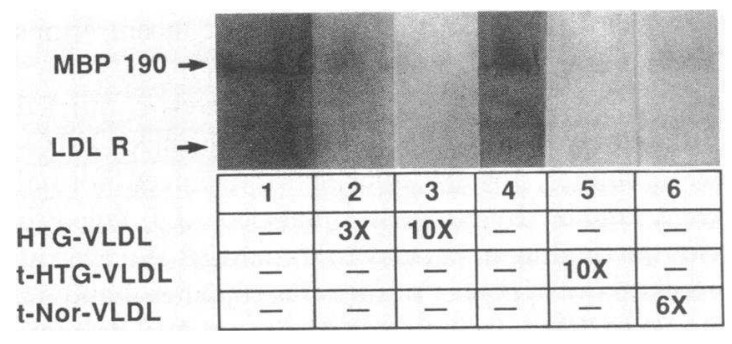

Figure 7. Binding of ${ }^{125}$ I-HTG-VLDL to MBP 190 is competed by HTG-VLDL, tryp-HTG-VLDL, and tryp-normal VLDL. P388D macrophages were harvested after $24 \mathrm{~h}$ growth in complete medium and extracted with Triton X-114; aliquots of aqueous phase extracts were electrophoresed and electrotransferred as described in Methods. The blocked nitrocellulose strips were incubated with ${ }^{125}$ I-HTGVLDL, $10 \mu \mathrm{g}$ protein/ml alone (lanes 1 and 4), or with 3-fold (lane 2) or 10-fold (lane 3) excess of unlabeled HTG-VLDL, a 10-fold excess of unlabeled tryp-HTG-VLDL (lane 5), or a sixfold excess of unlabeled tryp-normal VLDL (lane 6). The mobility of the bovine LDL receptor, visualized with ${ }^{125} \mathrm{I}-\beta$-VLDL, is indicated; molecular weight standards were used to calculate the apparent molecular weight of the binding protein (MBP 190).

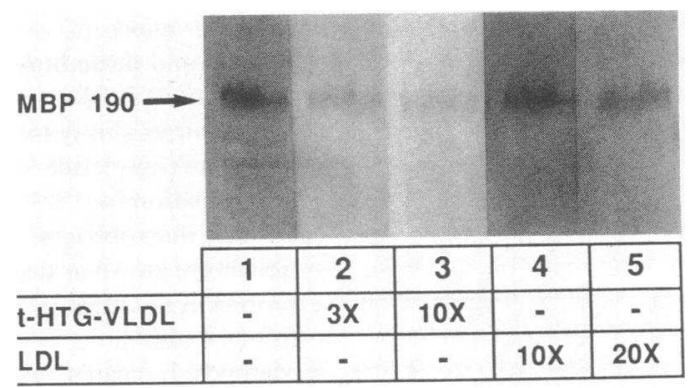

Figure 8. Binding of ${ }^{125}$ I-HTG-VLDL to MBP 190 is competed by tryp-VLDL but not by LDL. P388D ${ }_{1}$ macrophages were harvested after $24 \mathrm{~h}$ growth in complete medium and extracted with Triton X-114; aliquots of aqueous phase extracts were electrophoresed and electrotransferred as described in Methods. The nitrocellulose strips were incubated with ${ }^{125} \mathrm{I}-\mathrm{HTG}$-VLDL, $10 \mu \mathrm{g}$ protein $/ \mathrm{ml}$, alone (lane 1) or with a 3-fold (lane 2) or 10-fold (lane 3) excess of unlabeled tryp-VLDL or a 10-fold (lane 4) or 20-fold (lane 5) excess of unlabeled LDL, and exposed to x-ray film for $24 \mathrm{~h}$. Prestained $M_{\mathrm{r}}$ standards (Methods) were used to establish apparent molecular weights. The amount of ${ }^{125}$ I-HTG-VLDL bound to MBP 190 in each lane was quantified by cutting out this region of the nitrocellulose and a control region of equal size for gamma counting. After correction for background counts in the control region, $1,717 \mathrm{cpm}$ were bound to MBP 190 in lane $1,949 \mathrm{cpm}$ in lane $2,535 \mathrm{cpm}$ in lane 3,1,787 cpm in lane 4, and $1,653 \mathrm{cpm}$ in lane 5 .

$\mathrm{VLDL}_{1}$ (Fig. 9, left). Likewise, these preincubations had no effect on the nonspecific uptake of trypsinized VLDL, that is, the amount of iodinated VLDL taken up in the presence of an excess amount of unlabeled VLDL (Fig. 9, middle). Therefore,

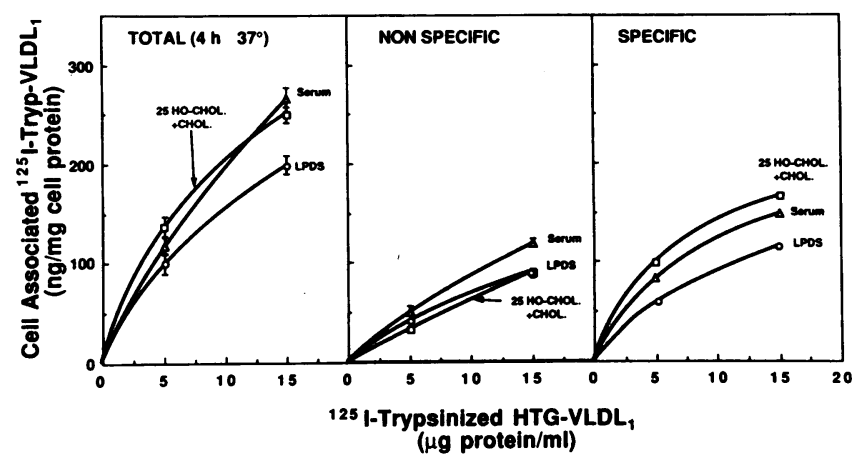

Figure 9. Effects of preincubation of macrophages in lipoprotein-deficient serum or with cholesterol and 25-hydroxycholesterol on uptake of ${ }^{125}$ I-tryp-VLDL. P388D ${ }_{1}$ macrophages were grown in $60 \mathrm{~mm}$ dishes in complete medium containing serum for $24 \mathrm{~h}$ and divided into three groups. The cells were washed with sterile saline and replenished with medium containing serum $(\Delta)$, medium containing $5 \%$ lipoprotein-deficient serum (O), or medium containing serum plus cholesterol, $16 \mu \mathrm{g} / \mathrm{ml}$, and 25 -hydroxycholesterol, $1 \mu \mathrm{g} / \mathrm{ml}$ (). After a 24-h preincubation, duplicate dishes of cells were incubated with the indicated concentrations of ${ }^{125}$ I-tryp-HTG-VLDL alone (left panel) or with an excess of unlabeled HTG-VLDL $(150 \mu \mathrm{g} / \mathrm{ml}$, middle panel) for $4 \mathrm{~h}$ at $37^{\circ} \mathrm{C}$ before the cell-associated radioactivity was determined, as described in Methods, as a measure of lipoprotein uptake. Each data point is the average of values from duplicate dishes; the range is indicated by error bars. Specific uptake (right panel) was calculated by subtracting the curves of the middle panel (nonspecific uptake) from those of the left-hand panel (total uptake). 


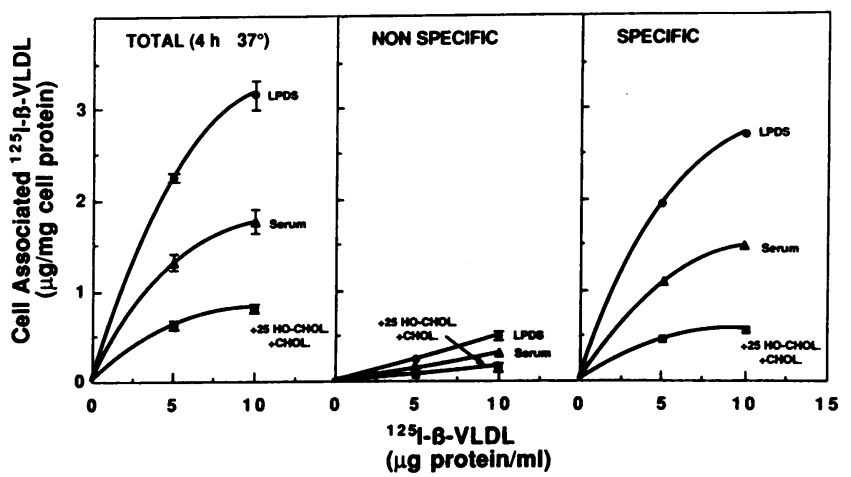

Figure 10. Effects of preincubation of macrophages in lipoproteindeficient serum or with cholesterol and 25-hydroxycholesterol on uptake of $\beta$-VLDL. Cell growth and preincubations in medium containing serum ( $\triangle)$, lipoprotein-deficient serum $(\bullet)$, or cholesterol (16 $\mu \mathrm{g} / \mathrm{ml})$ plus 25 -hydroxycholesterol $(1 \mu \mathrm{g} / \mathrm{ml})(\square)$, are described in the legend to Fig. 9. For measuring uptake, the cells were incubated with the indicated concentrations of ${ }^{125} \mathrm{I}-\beta$-VLDL from cholesterol-fed rabbits alone (left panel) or with excess unlabeled $\beta$-VLDL (100 $\mu \mathrm{g} / \mathrm{ml}$, middle panel) for $4 \mathrm{~h}$ at $37^{\circ}$ before cell-associated radioactivity, representing cellular uptake, was determined as described in Methods. Each data point is the average of values from duplicate dishes; the range is indicated by error bars. Specific uptake (right panel) was calculated by subtracting the curves of the middle panel (nonspecific uptake) from those of the left-hand panel (total uptake).

specific uptake, that is, total uptake of iodinated trypsinized VLDL in the absence of unlabeled trypsinized VLDL, minus nonspecific uptake, was similar whether or not the cells had been preincubated in lipoprotein-deficient serum or preincubated with 25-hydroxycholesterol and cholesterol (Fig. 9, right).

In contrast, as shown in Fig. 10, the macrophage uptake of iodinated $\beta$-VLDL isolated from cholesterol-fed rabbits is increased by preincubation of the cells in lipoprotein-deficient serum and is decreased by cholesterol loading, consistent with uptake of this lipoprotein being mediated predominantly by the regulatable LDL receptor. This is true for total uptake (Fig. 10, left) and for specific receptor-mediated uptake (Fig. 10, right). Nonspecific uptake was similar in the three groups of cells (middle).

The dramatically different regulation of uptake of trypVLDL and $\beta$-VLDL in whole cells studies is reflected in ligand blots of extracts of the three groups of cells (Fig. 11). HTGVLDL was used as a ligand to visualize all lanes since it binds efficiently both to the LDL receptor (10-13) and to MBP 190 (this report). As seen in lane $1,{ }^{125} \mathrm{I}-\mathrm{HTG}-\mathrm{VLDL}_{1}$ binds efficiently to the bovine adrenal LDL receptor. Lanes 2-7 contain aliquots of Triton X-114 extracts of murine $\mathrm{P}_{388 \mathrm{D}_{1} \text { macro- }}$ phages preincubated in medium containing serum $(S)$, LPDS $(-C)$, or 25-hydroxycholesterol plus cholesterol $(+C)$. The aqueous phase extracts $(A)$ were electrophoresed in lanes 2-4 at approximately equal protein concentrations and the detergent phase extracts $(D)$ at equal concentrations in lanes 5-7. Typically, MBP 190 partitions primarily into the aqueous phase (Fig. 11, lanes 2-4) and the macrophage LDL receptor partitions primarily into the detergent phase (Fig. 11, lane 7; reference 33), although occasionally some LDL receptor spills over into the aqueous phase of extracts of induced cells (Fig. 11, lane 4). The relative intensities of MBP 190 in lanes 2-4 of
Fig. 11 were equivalent, as judged by visual inspection, indicating that expression of MBP 190 was not regulated by these three different preincubations. In contrast, as can be seen in the detergent phase extracts (Fig. 11, lanes 5-7), the murine macrophage LDL receptor was induced by preincubation of the cells in lipoprotein-deficient serum for $24 \mathrm{~h}$ (Fig. 11, lane 7). At approximately equal protein concentrations, the LDL receptor was not detected in extracts of cells grown in the presence of complete medium containing serum (Fig. 11, lane 5 ), or in extracts of cells preincubated with 25-hydroxycholesterol and cholesterol (Fig. 11, lane 6). Exactly the same pattern of induction of the macrophage LDL receptor was observed when ${ }^{125}$-I- $\beta$-VLDL was used as a ligand; however, $\beta$-VLDL bound better to the LDL receptor than to MBP 190, indicating $\beta$-VLDL has a higher affinity for the LDL receptor than for MBP 190 (data not shown).

In four different regulatory experiments neither MBP 190 nor cellular uptake of tryp-VLDL increased upon incubation with LPDS, in contrast to the LDL receptor. Conversely, cellular uptake of tryp-VLDL and the expression of MBP 190 showed little to no downregulation after cholesterol loading, conditions that efficiently decreased the LDL receptor and cellular uptake of $\beta$-VLDL. These experiments also demonstrate that the $\mathrm{P} 388 \mathrm{D}_{1}$ macrophage LDL receptor appears similar to the bovine LDL receptor in apparent relative molecular mass (Fig. 11, lanes 1 and 7) and, like the bovine LDL receptor, binds HTG-VLDL (Fig. 11) but not trypsinized HTGVLDL (not shown).

$M B P 190$ is immunologically distinct from the $L D L$ receptor. Polyclonal antibodies were produced against the purified

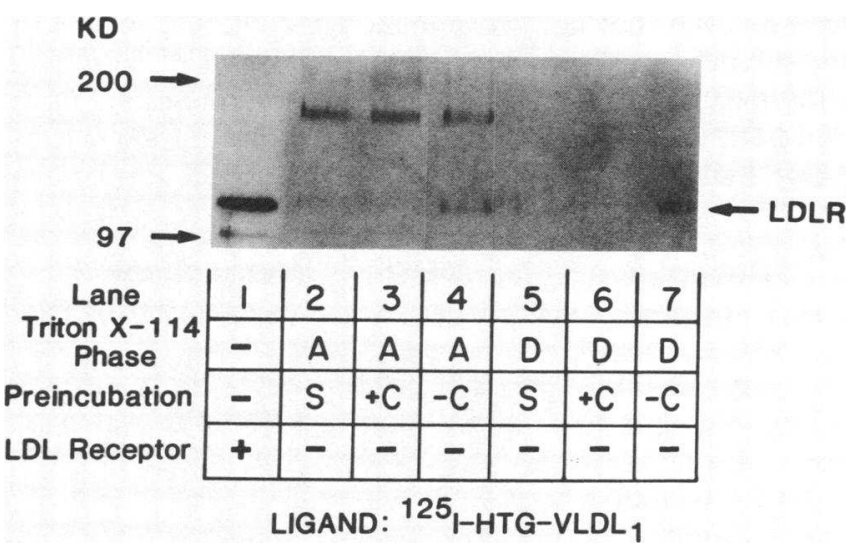

Figure 11. Effects of preincubation of macrophages in serum, lipoprotein-deficient serum, or with cholesterol plus 25-hydroxycholesterol on the expression of the LDL receptor and MBP 190. P388D cells were grown in $100 \mathrm{~mm}$ dishes ( 20 dishes per experimental group) in complete medium for $24 \mathrm{~h}$, washed, and then incubated for $24 \mathrm{~h}$ in complete medium containing serum $(S)$, lipoprotein-deficient serum $(-C)$, or in complete medium plus cholesterol (16 $\mu \mathrm{g} / \mathrm{ml})$ and 25 -hydroxycholesterol $(1 \mu \mathrm{g} / \mathrm{ml})(+C)$. The cells were harvested and extracted with Triton X-114 and the extracts phase separated as described in Methods. Aliquots of aqueous phase extracts $(A$, lanes 2-4) and detergent phase extracts $(D$, lanes 5-7) and the DEAE-cellulose-purified bovine adrenal LDL receptor as a marker (lane 1 ) were electrophoresed on a $6 \%$ polyacrylamide gel. After electrophoresis, proteins were transferred to nitrocellulose, blocked, incubated with ${ }^{125} \mathrm{I}-\mathrm{HTG}-\mathrm{VLDL}, 20 \mu \mathrm{g} / \mathrm{ml}$, dried, and exposed to x-ray film for $16 \mathrm{~h}$. Mobilities of the prestained relative molecular mass standards are indicated. 
bovine adrenal LDL receptor and the IgG fraction was purified and tested for its ability to block binding of lipoproteins to the LDL receptor and to MBP 190 in ligand blot analyses. The LDL receptor from the bovine adrenal cortex and macrophage Triton X-114 aqueous phase extracts were electrophoresed and transferred to nitrocellulose (Fig. 12). The nitrocellulose strips were then preincubated with either preimmune IgGs or with the anti-LDL receptor IgGs and then with labeled ligand. The anti-LDL receptor IgGs effectively blocked binding of HTG-VLDL to the LDL receptor (Fig. 12, lane 1). In contrast, the anti-LDL receptor IgGs failed to block binding of trypsinized VLDL to MBP 190 (Fig. 12, lane 3). Control preimmune IgGs did not block binding of HTG-VLDL to the LDL receptor (Fig. 12, lane 2), or tryp-VLDL to MBP 190 (Fig. 12, lane 4). In three separate experiments, the anti-LDL receptor IgG (up to $100 \mu \mathrm{g} / \mathrm{ml}$, a 20 -fold protein excess and a 130 -fold molar excess) failed to block binding of tryp-VLDL or HTGVLDL to MBP 190 but completely blocked binding of HTGVLDL (or $\beta$-VLDL, not shown) to the LDL receptor. Control immunoblots (not shown) demonstrated that the anti-LDL receptor IgG bound to the murine macrophage LDL receptor, but not to MBP 190. These experiments indicate that MBP 190 does not contain epitopes in common with the LDL receptor that are critical to lipoprotein binding.

Anti-LDL receptor antibodies do not block cellular uptake of tryp-VLDL. In addition, binding studies in whole cells demonstrated that anti-LDL receptor IgGs at concentrations up to $100 \mu \mathrm{g} / \mathrm{ml}$ (a 20-fold protein excess and $\sim 130$-fold molar excess) did not block the specific uptake and degradation of ${ }^{125}$ I-tryp-VLDL by P388D $_{1}$ cells, whereas tryp-VLDL effectively competed (Fig. $13 \mathrm{~A}$ ). Likewise, control nonimmune IgGs had no effect on uptake. In sharp contrast, the anti-LDL receptor IgGs, but not nonimmune IgGs, effectively blocked the specific uptake of ${ }^{125} \mathrm{I}-\beta$-VLDL by $\mathrm{P} 388 \mathrm{D}_{1}$ macrophages with upregulated LDL receptors (Fig. $13 \mathrm{~B}$ ), indicating these anti-LDL receptor IgGs block uptake via the murine macrophage LDL receptor. These experiments provide further evi-

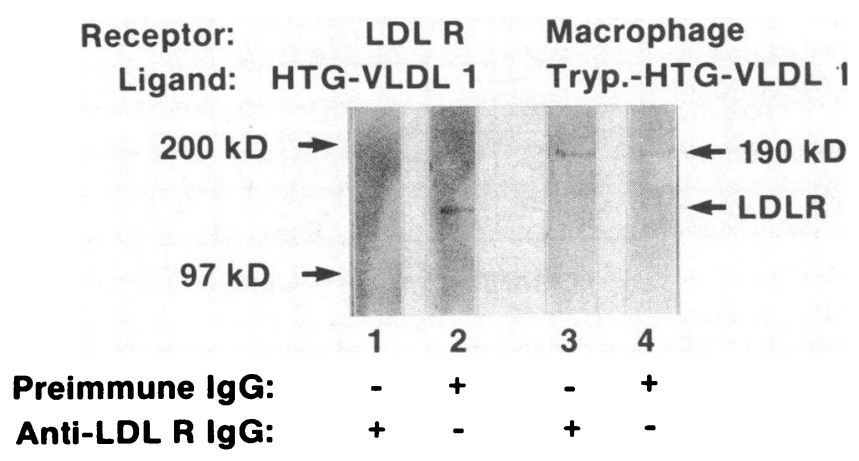

Figure 12. Anti-LDL receptor antibodies against the LDL receptor that block binding of HTG-VLDL to the LDL receptor do not block binding of tryp-VLDL to MBP 190 . The murine P388D 1 macrophages were grown in complete medium $1 \mathrm{~d}$, harvested, and extracted with Triton X-114. Aqueous phase extracts (lanes 3 and 4) and the partially purified bovine adrenal LDL receptor (lanes 1 and 2) were electrophoresed, electrotransferred, and blocked as described in Methods. Nitrocellulose strips were then incubated for $1 \mathrm{~h}$ at room temperature with purified IgGs against the LDL receptor (lanes 1 and 3 ) or purified preimmune IgGs (lanes 2 and 4 ), washed, incubated with ${ }^{125}$ I-HTG-VLDL to visualize the LDL receptor (lanes 1 and 2) or ${ }^{125}$ I-tryp-VLDL to visualize MBP 190 (lanes 3 and 4), washed, dried, and exposed to film for $16 \mathrm{~h}$.
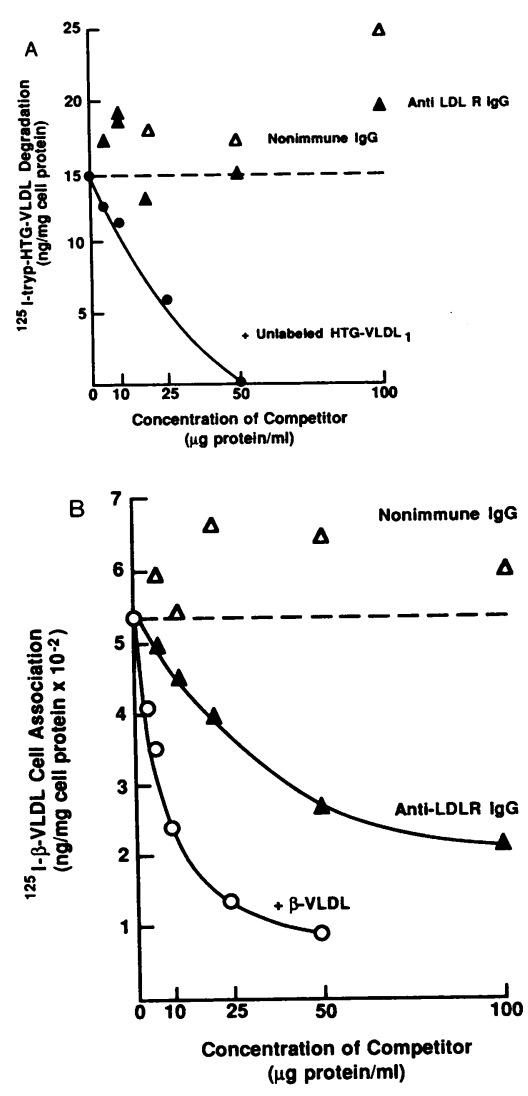

Figure 13. Anti-LDL receptor antibodies block cellular uptake of $\beta$-VLDL but not trypVLDL by $\mathrm{P} 388 \mathrm{D}_{1}$ macrophages. $(A)$ Cells were grown as described in the legend to Fig. 1, incubated with ${ }^{125}$ I-trypVLDL, $5 \mu \mathrm{g} / \mathrm{ml}$, alone or with the indicated concentration of unlabeled HTG-VLDL (॰), anti-LDL receptor IgG $(\Delta)$, or nonimmune IgG $(\Delta)$ for $4 \mathrm{~h}$ at $37^{\circ} \mathrm{C}$ before the media were processed to determine lipoprotein degradation. Each data point is the average of values from duplicate dishes, expressed as nanograms ${ }^{125}$ I-tryp-VLDL protein degraded/milligram cell protein. (B) Cells were preincubated for $36 \mathrm{~h}$ in medium containing lipoprotein-deficient serum, incubated with ${ }^{125} \mathrm{I}-\beta$-VLDL $(2.5$ $\mu \mathrm{g} / \mathrm{ml}$ ) alone or with the indicated concentrations of unlabeled $\beta$-VLDL (o), anti-LDL receptor $\operatorname{IgG}(\Delta)$, or nonimmune $\operatorname{IgG}(\Delta)$ for $4 \mathrm{~h}$ at $37^{\circ} \mathrm{C}$ before the cells were washed and the cell associated radioactivity determined as described in Methods. Each data point is the average of values from duplicate dishes, which varied by $<5 \%$, expressed as nanograms ${ }^{125} \mathrm{I}-\beta$-VLDL protein/milligram cell protein.

dence that there is a cellular pathway for high affinity uptake of triglyceride-rich lipoproteins in macrophages alternate to the LDL receptor pathway.

Cellular distribution of MBP 190. Ligand blotting analysis demonstrates that a binding protein for HTG-VLDL and tryp-VLDL similar to MBP 190 is present in Triton X-114 aqueous phase extracts of normal human monocytes cultured 3 d (Fig. 14, lanes 3 and 5). For comparison, MBP 190 from P388D 1 macrophages (Fig. 14, lanes 2 and 4) and the bovine LDL receptor (Fig. 14, lane 1) are shown. In human monocyte extracts, two proteins that bind HTG-VLDL and trypsinized HTG-VLDL are evident (Fig. 14, lanes 3 and 5, respectively). The predominant protein is very similar in electrophoretic mobility to MBP 190 of $\mathrm{P}_{388 D_{1}}$ extracts; the second binding protein has a lower mobility (higher apparent molecular weight). The relationship of these two binding proteins remains to be determined. These binding proteins are present in freshly isolated human monocytes before and for at least $5 \mathrm{~d}$ after adherence. Ligand blots of the detergent phase extracts of human monocytes did not exhibit any binding protein for tryp-VLDL or HTG-VLDL. Thus human monocyte-macrophages express a binding protein for HTG-VLDL and trypVLDL similar to MBP 190 from the murine macrophages in terms of ligand specificity, molecular weight, and detergent solubility.

In contrast, as previously published, cultured human fibro- 


\begin{tabular}{|c|c|c|c|c|c|}
\hline \multirow{2}{*}{$\begin{array}{l}\text { Ligand: } \\
\text { MBP } 190\end{array}$} & \multicolumn{3}{|c|}{ HTG-VLDL } & \multicolumn{2}{|c|}{ t-HTG-VLD } \\
\hline & & & $=$ & & $=0$ \\
\hline LDLR & $\rightarrow$ & & & & \\
\hline \multirow[b]{2}{*}{ LDL R } & 1 & 2 & 3 & 4 & 5 \\
\hline & + & - & - & - & - \\
\hline \multirow{2}{*}{$\begin{array}{l}\text { P388D }_{1} \\
\text { H.M. }\end{array}$} & - & + & - & + & - \\
\hline & - & - & + & - & + \\
\hline
\end{tabular}
$20 \%$ autologous serum to allow monocytes to adhere. After nonadherent cells were removed, the monocytes were incubated in the same medium for $3 \mathrm{~d}$ in a $\mathrm{CO}_{2}$ incubator, harvested, and extracted with Triton X-114 as described in Methods. Aliquots of the aqueous phase of human monocyte extracts were electrophoresed in lanes 3 and 5 , the partially purified bovine adrenal LDL receptor in lane 1 , and aqueous phase extracts of $P 388 D_{1}$ macrophages in lanes 2 and 4. The ligand for lanes 1-3 was ${ }^{125} \mathrm{I}-\mathrm{HTG}-\mathrm{VLDL}, 20 \mu \mathrm{g} / \mathrm{ml}$, and for lanes 4 and $5,{ }^{125} \mathrm{I}$-tryp-VLDL, $20 \mu \mathrm{g} / \mathrm{ml}$. Prestained relative molecular mass standards were used to calculate apparent molecular weight of MBP 190.

blasts do not express a high affinity receptor pathway for trypsinized VLDL $(10,11,26)$. Moreover, ligand blots indicate that cultured human skin fibroblasts do not possess a binding protein similar to MBP 190 or any protein that binds trypsinized HTG-VLDL in either aqueous or detergent-phase Triton X-1 14 extracts or in octylglucoside extracts (data not shown). Thus, the $190-\mathrm{kD}$ binding protein appears to be present in human monocytes and murine macrophages that take up human triglyceride-rich lipoproteins by a high affinity pathway, but not in a nonmacrophage cell type such as the cultured human skin fibroblast that, however, can express high levels of the LDL receptor. Therefore, the cellular distribution of the $\sim$ 190-kD binding protein and high affinity cellular uptake of tryp-VLDL differs from that of the ubiquitous $L D L$ receptor pathway.

\section{Discussion}

Previous and current evidence indicates that macrophages have an alternate receptor pathway for abnormal human triglyceride-rich lipoproteins distinct from the LDL receptor. First, direct and competitive binding, uptake, degradation, and triglyceride accumulation studies indicate that the ligand specificity of the macrophage receptor is distinct from that of the LDL receptor: apoE is not necessary for the binding of triglyceride-rich particles to the macrophage receptor, but is essential for binding to the LDL receptor, including the murine macrophage receptor $(7,10-13,17,26)$. Second, regulation studies demonstrate that the cellular uptake and degradation of trypsinized VLDL by the macrophages is not increased by preincubation in lipoprotein-deficient medium and shows little to no decrease after the cells are preincubated in 25-hydroxycholesterol and cholesterol, in direct contrast to the regulated uptake of $\beta$-VLDL by the LDL receptor. Third, an anti-LDL receptor polyclonal antibody shown to block LDL receptormediated uptake of $\beta$-VLDL by P388D $_{1}$ macrophages and to block binding of HTG-VLDL to the LDL receptor did not inhibit cellular uptake of trypsinized VLDL. Fourth, the cellular distribution of the pathway for uptake of trypsinized VLDL differs from that of the ubiquitous LDL receptor and is not expressed in cultured human fibroblasts $(10,11,26)$. Fifth and finally, ligand blotting analyses demonstrate that the murine macrophage LDL receptor is not responsible for high affinity uptake and degradation of trypsinized VLDL. The inducible murine macrophage LDL receptor, like the bovine adrenal LDL receptor (13) and the human fibroblast LDL receptor (10-13), binds HTG-VLDL and $\beta$-VLDL (8), but fails to bind tryp-VLDL in ligand blots.

In summary, whole cell studies in $\mathrm{P}_{388 \mathrm{D}_{1}}$ macrophages indicate that the macrophage site that binds tryp-VLDL and HTG-VLDL fulfills the criteria for receptor-mediated uptake, that is, high affinity, saturable binding, appropriate competition, and an intracellular physiological response (triglyceride accumulation). Furthermore, these studies indicate that there exists an alternate receptor pathway for uptake of abnormal human triglyceride-rich lipoproteins that is distinct from the LDL receptor in terms of ligand specificity, regulation, immunological characteristics, and cellular distribution.

In studies undertaken to visualize candidate proteins for the receptor itself, ligand blotting analyses revealed MBP 190 that binds HTG-VLDL and tryp-VLDL. MBP 190 shares the characteristics of the cellular receptor pathway for uptake of HTG-VLDL and tryp-VLDL in terms of ligand specificity, regulation, cellular distribution, and immunological distinction from the LDL receptor. MBP 190 differs from the macrophage LDL receptor in several respects. First, MBP 190 differs in ligand specificity: tryp-VLDL devoid of apoE binds to MBP 190, but fails to bind to the bovine LDL receptor or the murine macrophage LDL receptor. Competitive ligand blots show that HTG-VLDL and tryp-VLDL but not LDL or normal VLDL compete for binding to MBP 190. Second, MBP 190 has a different apparent molecular weight from the murine LDL receptor or the bovine LDL receptor $(\sim 190$ vs. $\sim 130 \mathrm{kD})$. Third, MBP 190 is distinct from the murine LDL receptor in terms of detergent solubility: MBP 190 partitions primarily into the aqueous phase of Triton X-114 extracts after phase separation, whereas the murine macrophage LDL receptor partitions primarily into the detergent phase. Fourth, MBP 190 and the murine LDL receptor are distinct in terms of regulation: cellular uptake of tryp-VLDL and MBP 190, in contrast to cellular uptake of $\beta$-VLDL and the murine macrophage LDL receptor, are not increased by preincubation in lipoprotein-deficient serum nor decreased by preincubation with cholesterol or 25-hydroxycholesterol. Indeed, MBP 190 is found in extracts of $P 388 D_{1}$ macrophages grown under conditions where no LDL receptors are expressed or detected by ligand blotting and these were the conditions used in cellular binding studies. Fifth, MBP 190 is found in murine and human monocytes but not in human fibroblasts, which express LDL receptors, showing the same restricted cellular distribution as for high affinity uptake of tryp-VLDL. Sixth, as in cellular uptake studies, the binding of tryp-VLDL or HTGVLDL to MBP 190 is not inhibited by anti-LDL receptor antibodies that block cellular uptake of $\beta$-VLDL by P388D, cells and block binding of HTG-VLDL to the LDL receptor.

These studies suggest that MBP 190, a macrophage lipoprotein binding protein distinct from the LDL receptor, is a likely candidate protein for the alternate receptor for the high affinity uptake and degradation of abnormal human triglyceride-rich lipoproteins by macrophages.

The binding determinants in triglyceride-rich lipoproteins for this distinct macrophage receptor pathway or for MBP 190 remain unknown. Native human lipoproteins that are inter- 
nalized via this pathway (plasma chylomicrons and HTGVLDL) contain apoB, apoE, and apoC proteins. Removal of some to all apoE from HTG-VLDL by thrombin-cleavage (2, 3) or trypsinization (this report) does not diminish uptake of HTG-VLDL ${ }_{1}$ by macrophages or binding to MBP 190, indicating that apoE is not required for interaction with the receptor or with MBP 190. Rabbit $\beta$-VLDL contain little to no apoC peptides, yet competition studies in whole cells indicate $\beta$-VLDL bind to macrophage receptors that also bind human chylomicrons (1-5, 9, 15), HTG-VLDL $(1-3,5)$, and thrombin- or trypsin-treated HTG-VLDL (1-3, and this report) as well as to MBP 190, suggesting apoC peptides are not required for binding. Since each of the native and protease-modified human lipoproteins that bind to MBP 190 and are internalized via the alternate macrophage receptor pathway minimally contains apoB or apoB fragments, we suggest that one or more domains of apoB are involved in binding. These domain(s) would be expressed in lipoproteins that bind to this receptor (plasma chylomicrons, HTG-VLDL, thrombin-treated HTGVLDL, and trypsin-treated normal and HTG-VLDL) but not in the apoB-containing lipoproteins that do not bind with high affinity to the receptor (normal VLDL and LDL). Since the lipoproteins that bind contain apoB species or fragments in addition to apoB-100, in contrast to normal VLDL and LDL, a domain expressed normally or after degradation of apoB may be involved in binding of these lipoproteins $(10,11)$.

An alternate and distinct macrophage receptor pathway for abnormal triglyceride-rich lipoproteins is potentially important in clinicopathologic phenomena such as in the accumulation of foam cells in hypertriglyceridemic diabetics (35), in the development of premature atherosclerosis associated with certain hypertriglyceridemias (21), and in the increased incidence of myocardial infarction associated with hypertriglyceridemia $(36,37)$. Uptake of abnormal triglyceride-rich lipoproteins by this alternate macrophage receptor pathway may be involved in the conversion of macrophages into lipid-filled foam cells that accumulate in some forms of hypertriglyceridemia (21). The presence of MBP 190-like binding proteins for HTGVLDL in human monocytes underscores the potential role of this pathway in humans. Moreover, the maximal binding, uptake, degradation, and triglyceride accumulation in macrophages via the distinct macrophage receptor observed in vitro

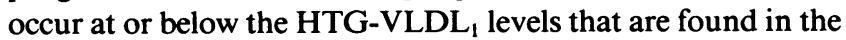
plasma of many hypertriglyceridemic subjects. Thus there is sufficient $\mathrm{HTG}-\mathrm{VLDL}_{1}$ present in these subjects' plasma to saturate these receptors present on monocytes or macrophages.

Observations in diabetic subjects support the possibility that these phenomena can occur in vivo. Triglyceride-rich foam cells are found in eruptive xanthomas in untreated hypertriglyceridemic (type 5) diabetics (35). Insulin treatment of these subjects results in a lowering of plasma triglyceride levels, after which the triglycerides in the foam cells rapidly diminish, leaving cholesterol as the predominant lipid (35). A similar process could occur in the genesis of arterial foam cells in hypertriglyceridemic subjects, many of whom suffer from premature atherosclerosis.

\section{Acknowledgments}

We thank Flora B. Brown for expert assistance with the tissue cultures, Ruth Schultz and Amy Knowlton for technical assistance, and Jacki McCoy for editorial assistance. We are grateful to Dr. Peter H. Jones and Dr. John R. Guyton for providing plasma from hypertriglyceridemic subjects, Dr. David Yawn for assistance in isolating human mononuclear cells, Dr. William W. Mantulin for providing $\beta$-VLDL and plasma from cholesterol-fed rabbits, Dr. John W. Fenton II for providing purified human $\alpha$-thrombin, and Dr. Antonio M. Gotto, Jr., for his continued encouragement.

This work was supported in part by a Specialized Center of Research (SCOR) in Arteriosclerosis (grant HL27341) and grant-in-aid 83-766 from the American Heart Association (Dr. Gianturco). Dr. Gianturco is an Established Investigator of the American Heart Association.

\section{References}

1. Gianturco, S. H., W. A. Bradley, A. M. Gotto, Jr., J. D. Morrisett, and D. L. Peavy. 1982. Hypertriglyceridemic very low density lipoproteins induce triglyceride synthesis and accumulation in mouse peritoneal macrophages. J. Clin. Invest. 70:168-168.

2. Gianturco, S. H., S. A. Brown, D. P. Via, and W. A. Bradley. 1986. The $\beta$-VLDL receptor pathway of murine $P 388 D_{1}$ macrophages. J. Lipid Res. 27:412-420.

3. Gianturco, S. H., A. M. Gotto, Jr., and W. A. Bradley. 1985. Hypertriglyceridemia: lipoprotein receptors and atherosclerosis. $A d v$. Exp. Med. 183:47-71.

4. Van Lenten, B. J., A. M. Fogelman, M. M. Hokom, L. Benson, M. E. Haberland, and P. A. Edwards. 1983. Regulation of the uptake and degradation of $\beta$-very low density lipoprotein in human monocyte-macrophages. J. Biol. Chem. 258:5151-5157.

5. Nestel, P. J., T. Billington, and J. Bazelmans. 1985. Metabolism of human plasma triacylglycerol-rich lipoproteins in rodent macrophages: capacity for interaction at $\beta$-VLDL receptor. Biochim. Biophys. Acta. 837:314-324.

6. Goldstein, J. L., Y. K. Ho, M. S. Brown, T. L. Innerarity, and R. W. Mahley. 1980. Cholesteryl ester accumulation in macrophages resulting from receptor-mediated uptake and degradation of hypercholesterolemic canine $\beta$-very low density lipoproteins. J. Biol. Chem. 255:1839-1848.

7. Koo, C., M. E. Wernette-Hammond, and T. L. Innerarity. 1986. Uptake of canine $\beta$-VLDL by mouse peritoneal macrophages is mediated by a low-density lipoprotein receptor. J. Biol. Chem. 261(24):11194-11201.

8. Ellsworth, J. L., F. B. Kraemer, and A. D. Cooper. 1987. Transport of $\beta$-VLDL and chylomicron remnants by macrophages is mediated by the LDL receptor pathway. J. Biol. Chem. 262(5):23162325.

9. Van Lenten, B. J., A. M. Fogelman, R. L. Jackson, S. Shapiro, M. E. Haberland, and P. A. Edwards. 1985. Receptor-mediated uptake of remnant lipoproteins by cholesterol-loaded human monocyte-macrophages. J. Biol. Chem. 260:8783-8788.

10. Gianturco, S. H., A. M. Gotto, Jr., S.-L. C. Hwang, J. B. Karlin, A. H. Y. Lin, S. C. Prasad, and W. A. Bradley. 1983. Apolipoprotein E mediates uptake of $S_{f} 100-400$ hypertriglyceridemic very low density lipoproteins by the low density lipoprotein receptor pathway in normal human fibroblasts. J. Biol. Chem. 258:4526-4533.

11. Bradley, W. A., S.-L. C. Hwang, J. B. Karlin, A. H. Y. Lin, S. C. Prasad, A. M. Gotto, Jr., and S. H. Gianturco. 1984. Low-density lipoprotein receptor binding determinants switch from apolipoprotein E to apolipoprotein B during conversion of hypertriglyceridemic verylow-density lipoprotein to low-density lipoproteins. J. Biol. Chem. 259:14728-14735.

12. Gianturco, S. H., and W. A. Bradley. 1986. The role of apolipoprotein processing in receptor recognition. Methods Enzymol. 128(B):319-344.

13. Brown, S. A., D. P. Via, A. M. Gotto, Jr., W. A. Bradley, and S. H. Gianturco. 1986. Hypertriglyceridemic very low density lipoproteins $S_{\mathrm{f}} 100-400$ bind to the isolated low density lipoprotein receptor exclusively via ApoE. Biochem. Biophys. Res. Commun. 139:333-340.

14. Floren, C. H., J. J. Albers, B. J. Kudchodkar, and E. L. Bier- 
man. 1981. Receptor-dependent uptake of human chylomicron remnants by cultured skin fibroblasts. J. Biol. Chem. 256:425-433.

15. Baker, D. P., B. J. Van Lenten, A. M. Fogelman, P. A. Edwards, C. Kean, and J. A. Berliner. 1984. LDL, scavenger, and $\beta$-VLDL receptors on aortic endothelial cells. Arteriosclerosis. 4:248-255.

16. Via, D. P., A. L. Plant, I. F. Craig, A. M. Gotto, Jr., and L. C. Smith. 1985. Metabolism of normal and chemically modified low density lipoproteins by macrophage cell lines of murine and human origin. Biochim. Biophys. Acta. 833:417-428.

17. Krul, E. S., M. J. Tikkanen, T. G. Cole, J. M. Davie, and G. Schonfeld. 1985. Roles of apolipoproteins B and E in the cellular binding of very low density lipoproteins. J. Clin. Invest. 75:361-369.

18. Goldstein, J. L., and M. S. Brown. 1974. Binding and degradation of low density lipoproteins by cultured human fibroblasts. J. Biol. Chem. 249:5153-5162.

19. Böyum, A. 1968. Isolation of mononuclear cells and granulocytes from human blood. Scand. J. Clin. Lab. Invest. 97(Suppl. 21):77-89.

20. Johnson, W. D., B. Mei, and Z. A. Cohn. 1977. The separation, long-term cultivation, and maturation of the human monocyte. $J$. Exp. Med. 146:1613-1626.

21. Fredrickson, D. S., J. L. Goldstein, and M. S. Brown. 1978. The familial hyperlipoproteinemias. In The Metabolic Basis of Inherited Diseases. 4th edition. J. G. Stanbury, M. F. Wyngaarden, and D. S. Fredrickson, editors. McGraw-Hill Book Co., New York. 604-655.

22. Havel, R. J., H. A. Eder, and J. J. Bragdon. 1955. The distribution and chemical composition of ultracentrifugally separated lipoproteins in human serum. J. Clin. Invest. 34:1345-1353.

23. Lindgren, F. T., L. C. Jensen, and F. T. Hatch. 1972. The isolation and quantitative analysis of serum lipoproteins. In Blood Lipids and Lipoproteins. G. J. Nelson, editor. Wiley Interscience, New York. 181-274.

24. Lowry, O. H., N. J. Rosebrough, A. L. Farr, and R. J. Randall. 1951. Protein measurement with the Folin phenol reagent. J. Biol. Chem. 193:265-275.

25. Helenius, A., and K. Simons. 1971. Removal of lipids from human plasma low density lipoprotein by detergents. Biochemistry. 10:2542-2547.

26. Bradley, W. A., and S. H. Gianturco. 1986. ApoE- is necessary and sufficient for binding of large triglyceride-rich lipoproteins to the LDL receptor; apoB is unnecessary. J. Lipid Res. 27:40-48.

27. Bradley, W. A., M. F. Rohde, and A. M. Gotto, Jr. 1980. Studies on the primary structure of apolipoprotein-B. Ann. NY Acad. Sci. 348:87-103.

28. Bilheimer, D. W., S. Eisenberg, and R. I. Levy. 1973. The metabolism of very low density lipoprotein proteins. I. Preliminary in vitro and in vivo observations. Biochim. Biophys. Acta. 250:212-221.

29. Schneider, W. J., U. Beisiegel, J. L. Goldstein, and M. S. Brown. 1982. Purification of the low density lipoprotein receptor, an acidic glycoprotein of 164,000 molecular weight. J. Biol. Chem. 257:2664-2673.

30. Corthier, C. T., E. Boschetti, and J. Charley-Poulain. 1984. Improved method for IgG purification from various animal species by ion exchange chromatography. J. Immunol. Methods. 66:75-79.

31. Bordier, C. 1985. Phase separation of integral membrane proteins in Triton X-114 solution. J. Biol. Chem. 256:1604-1607.

32. Dresel, H. A., I. Otto, H. Weigel, G. Schettler, and D. P. Via. 1984. A simple and rapid anti-ligand enayme immunoassay for visualization of low-density lipoprotein membrane receptors. Biochim. Biophys. Acta. 795:452-457.

33. Laemmli, U. K. 1970. Cleavage of structural proteins during the assembly of the head of bacteriophage T4. Nature (Lond.). 227:680-685.

34. Daniel, O. D., W. J. Schneider, J. L. Goldstein, and M. S. Brown. 1983. Visualization of lipoprotein receptors by ligand blotting. J. Biol. Chem. 258(7):4606-4611.

35. Parker, F., J. D. Bagdade, G. F. Odland, and E. L. Bierman. 1970. Evidence for the chylomicron origin of lipids accumulating in diabetic eruptive xanthomas: a correlative lipid biochemical, histochemical, and electron microscopic study. J. Clin. Invest. 49:21722187.

36. Carlson, L. A., and L. E. Bottiger. 1972. Ischaemic heart-disease in relation to fasting values of plasma triglycerides and cholesterol. Lancet. i:865-868.

37. Aberg, H., H. Lithell, I. Selinus, and H. Hedstrand. 1985. Serum triglycerides are a risk factor for myocardial infarction but not for angina pectoris. Atherosclerosis. 54:89-97. 